\title{
Assessing the effect of recovery programs for salmon (Salmo salar Linnaeus, 1758) at its Southern limit in Europe: application of segmented regression models to long-term data from the Ulla River
}

\author{
Paula Saavedra-Nieves ${ }^{1}$, Rosa María Crujeiras ${ }^{2}$, Rufino Vieira-Lanero ${ }^{3,}$, Pablo Caballero $^{4}$ \\ and Fernando $\mathrm{Cobo}^{3,5}$
}

${ }^{1}$ Departamento de Estatística, Análise Matemática e Optimización. Facultade de Medicina, Universidade de Santiago de Compostela, Santiago de Compostela, Spain.

2 Departamento de Estatística, Análise Matemática e Optimización. Facultade de Matemáticas, Universidade de Santiago de Compostela, Santiago de Compostela, Spain.

3 Estación de Hidrobioloxía 'Encoro do Con', Universidade de Santiago de Compostela, Pontevedra, Spain.

${ }^{4}$ Servicio de Patrimonio Natural de Pontevedra. Consellería de Medio Ambiente, Territorio e Vivenda. Xunta de Galicia.

5 CRETUS - Cross-Research in Environmental Technologies, Universidade de Santiago de Compostela, Santiago de Compostela, Spain.

* Corresponding author: rufino.vieira@usc.es

Received: 24/05/19 Accepted: 09/01/20

\begin{abstract}
Assessing the effect of recovery programs for salmon (Salmo salar Linnaeus, 1758) at its Southern limit in Europe: application of segmented regression models to long-term data from the Ulla River
\end{abstract}

The abundance of Atlantic salmon in Europe has declined throughout its native range. One of the main causes is low marine survival, which has been mainly attributed to overexploitation at sea, but global warming, decreased zooplankton abundance in the North Atlantic and local changes in freshwater conditions have been also blamed. It has been also pointed out that Southern populations experience the greatest decline, but information from these areas in Europe is scarce, and also in Spain there are few long-term data series related with the salmon recovery programs carried out.

In this paper, we analyse a long-term data set $(1992$ - 2018) provided by a fish-trap located in the Ulla River (Galicia, NW Spain), at the southern limit of the salmon distribution range. Salmon restocking programs have been carried out in this river from 2000, and although this management technique is widely accepted, it is necessary to document the fate of those individuals to evaluate their success. Segmented regression models (or piecewise regression) are applied here for the first time to estimate the value of the explanatory variable (the so called break-point) which can indicate the potential success of the recovery program in this river.

Data analysis suggest a gradual population increase to the early 1990s, then remained relatively stable until 2007 and increased thereafter due to an increase in the number of wild salmon entering the river. An increase in the frequency of appearance of 3SW salmon since 2009 was detected, both including previous spawners and individuals at its first spawning migration after three consecutive winters at sea. Data suggest an increase in number of wild salmon entering the river. Restoring river connectivity has also helped to enhance this population.

We finally consider that the increase in the number of returning salmons in the Ulla River achieved over this period is due not only to the good management and conservation practices related to salmon stocking, but also to the connectivity restoration in the river and to a higher marine survival rate.

Key words: piecewise regression, spawning migration, supportive breeding, marine survival, connectivity, fish trap, Galicia, Spain 


\section{RESUMEN \\ Evaluando el efecto de los programas de recuperación del salmón (Salmo salar Linnaeus, 1758) en su límite sur en Europa: aplicación de los modelos de regresión segmentada a una serie larga de datos del río Ulla}

La abundancia del salmón Atlántico en Europa ha sufrido un declive en su área de distribución. Una de las causas principales es la baja supervivencia marina, que se ha atribuido principalmente a la sobreexplotación, pero también el calentamiento global, la disminución de la abundancia de zooplancton en el Atlántico norte y los cambios locales en las condiciones fluviales. También se ha indicado que el mayor declive corresponde a las poblaciones más meridionales, pero la información sobre estas áreas en Europa es escasa.

En España los estudios sobre el salmón basados en series de datos que abarquen largos periodos de tiempo son también escasos. Este trabajo analiza los datos proporcionados entre 1992 y 2018 por un capturadero situado en el rio Ulla (Galicia, NO de España), en el límite sur del rango de distribución del salmón, donde se han realizado repoblaciones desde el año 2000 para mejorar la población de salmón. Esta técnica está ampliamente aceptada, pero es necesario documentar el destino de los individuos repoblados para validar su éxito. El estudio aplica por primera vez los modelos de regresión segmentada para determinar el valor de la variable (el llamado punto de ruptura) que indique el éxito potencial de estas repoblaciones.

Los resultados sugieren que la población aumentó gradualmente en la década de 1990, después se mantuvo relativamente estable hasta 2007 y luego creció al aumentar el número de salmones remontantes. Se detectó un aumento en la frecuencia de aparición de salmones 3SW desde 2009 (tanto ejemplares que ya habian desovado anteriormente como individuos en su primera migración tras tres inviernos marinos consecutivos). Los datos sugieren que aumentó el número de salmones salvajes que remontaron el río.

Se considera que el aumento del número de salmones de retorno capturados en el río Ulla a lo largo de este periodo se debe no solo a las buenas prácticas de manejo y conservación relacionadas con las repoblaciones, sino también a la restauración de la conectividad fluvial y al aumento de la supervivencia marina.

Palabras clave: regresión por partes, migración reproductora, repoblación, supervivencia marina, conectividad, trampa para peces, Galicia, España

\section{INTRODUCTION}

Segmented regression (also called piecewise, change-of-phase, hockey stick, and joinpoint regression) has been used to fit stock-recruitment and individual growth curves for fish, to estimate size-and age-related mortality rates in fish, and to identify critical thresholds for environmental features (Brenden \& Bence, 2008 and references herein; Sonderegger et al., 2009). One clear advantage of using piecewise regression to fit segmented catch curves is that the imposed continuity restriction among segments avoids the jumps and falls that can result when separate linear regression models are fit to nonlinear ecological responses. In particular, Rincón \& Lobón-Cerviá (2002) and Rosenfeld $\&$ Taylor (2009) have used these models in salmonid research.

Atlantic salmon (Salmo salar Linnaeus, 1758) has shown a dramatic decline in abundance in the 1970s and populations have not yet recovered to previous levels of abundance (see Nicola et al., 2018 and references herein). As diadromous fish,
Atlantic salmon is affected by factors influencing survival at freshwater, estuarine and oceanic habitats. Some authors have addressed that one of the main drivers for stocking Atlantic salmon has been poor marine survival (Gurney et al., 2008; Kennedy et al., 2012), which can substantially reduce the numbers of adult salmon returning to spawn and can lead to population decline. Thus, the decreased marine survival has been mainly attributed to overexploitation, global warming and decreased zooplankton abundance in the North Atlantic but local conditions at rivers are also blamed (Saloniemi et al., 2004; ICES 2018a; Nicola et al., 2018).

As the opportunities for influencing marine survival are very limited, salmon management is predominantly focused on the freshwater life stages, particularly in maximizing production of freshwater emigrants. This has resulted in the common use of hatchery production and restocking of wild populations in an attempt to enhance salmon stocks (Jokikokko \& Jutila, 1998; Einum \& Fleming, 2001; Bacon et al., 2015). However, such practices have been widely criticized for 
both their low efficiency in preventing wild population declines and their potential contribution to fitness reduction (Aprahamian et al., 2003; Saloniemi et al., 2004; Araki et al., 2008; Milot et al., 2012). Genetic introgression is another issue related to the stocking programs. In Spain, researchers agree that introgression is a consequence of the abundant stock transfers carried out in the XX century using foreign genomes native to northern European countries to improve the southern European populations (Moran et al., 2005; Ayllon et al., 2006; Campos et al., 2008; Machado-Schiaffino et al., 2007; Horreo et al., 2011a, b). Captive breeding practices based on artificial spawning of native adults have been improved, but significant fitness decrease can persist and consequently hatchery-reared populations do not perform as well in the natural environment as their wild counterparts (Jonsson et al., 2003; Saloniemi et al., 2004; Jokikokko et al., 2006; Araki et al., 2007, 2009; Christie et al., 2012). Because conservation stocking only takes place at low stock levels, the result should be a clear and substantial increase in recruitment for fish populations that show compensatory dynamics, such as salmon. The achievement of successful management and conservation practices thus requires documenting the fate of hatchery-reared individuals released in the wild.

It has been also pointed out that the ongoing decline in Atlantic salmon abundance is most pronounced in the southern part of its distribution area (Parrish et al., 1998; Perez et al., 2005; Jonsson \& Jonsson, 2009). Information from these areas in Europe is scarce (Nicola et al., 2018) but, according to ICES (2013) the catches in Atlantic rivers of southern Europe have fallen down and the numbers of multi-sea-winter specimens have greatly reduced. This severe decline of Atlantic salmon, which is nearing the southern limit of its range in Galicia (NW Spain), has highlighted the need to develop recovery and conservation programs for this species.

There are few long-term data series on the Spanish salmon related with recovery programs (Braña et al., 1995; Blanco et al., 2005; Campos et al., 2008; Horreo et al., 2011c). In this paper the segmented regression models (or piecewise regression) will be used for the first time to analyse a long-term data series and evaluate the potential success of the restocking program carried out in the Ulla River. The segmented regression analysis provides a value for an explanatory variable (the so called break-point) which implies a change in the values of the trend or slope parameters for the regression function, preserving continuity.

The main goal of the present study is to ascertain the usefulness of segmented regression models to assess the real success of the stocking program that is being conducted since 2000 to restore the Atlantic salmon population in the Ulla River.

\section{MATERIALS AND METHODS}

\section{Study area}

The Ulla River (catchment area: $2803 \mathrm{~km}^{2}$; length: $132 \mathrm{~km}$; mean flow: $79.3 \mathrm{~m} / \mathrm{s}$ ) is the second Galician river in magnitude, after the Miño River. The river flows across the middle of Galicia in a southwesterly direction, and it finally drains into the Atlantic Ocean through the Ria de Arousa ( $42^{\circ} 40^{\prime} 41^{\prime \prime}$ north latitude). Geologically, the Ulla catchment is mainly comprised of schist and granitic rocks, representing a lowland river with clay substrate and a low level of mineralisation. Water temperatures range from $2.2{ }^{\circ} \mathrm{C}$ to $23.4{ }^{\circ} \mathrm{C}$. January is the coldest month with an average of $11^{\circ} \mathrm{C}$ and August the warmest with an average temperature of $17.3^{\circ} \mathrm{C}$.

The accessibility for migratory fish in the Ulla is limited by a hydroelectric power station located $80 \mathrm{~km}$ from the mouth (Portodemouros dam), which causes severe flow regulation and habitat disturbance downstream.

Data on salmon population in the Ulla River were provided by a permanent fish trap placed at Ximonde dam ( $\left.42^{\circ} 44^{\prime} 44^{\prime \prime} \mathrm{N}, 8^{\circ} 27^{\prime} 50^{\prime \prime} \mathrm{W}\right)$, which is located $40 \mathrm{~km}$ above the river mouth and $16 \mathrm{~km}$ upstream of the tidal limit. Downstream Ximonde another two small mill dams can obstruct or delay the fish upstream migration. About $25 \mathrm{~km}$ from the river mouth is Sinde dam, which was partially demolished by a flood in 2016, and $3 \mathrm{~km}$ upstream is the Couso dam, where a vertical slot fish ladder was built in 2004 . 
Ximonde trap started working in 1992. Facilities include two fishway devices (a pool and weir ladder and a Denil-type) provided with a $\mathrm{V}$-shaped fish entrance. A smolt permanent trap for downstream migrators was also installed in an adjacent canal. The traps are checked at least three times a day, and every two hours during the peak season.

\section{Datasets}

In this analysis, we have used a dataset of 3508 returning adult salmons (563 restocked and 2945 wild salmon) captured at Ximonde trap over the course of 27 years, from 1992 to 2018 . All the salmons were measured (fork length, to the nearest $\mathrm{mm}$ ), weighed (nearest $0.1 \mathrm{~g}$ ), and a scale sampling was also performed to provide the fish age. However, the sex ratio was based only on secondary sexual characters of the autumn fish, and only 973 autumn salmon were sexed: 557 females and 416 males. Although these data are not yet available in a public repository, they are available for researchers upon request to the Directorate General of Natural Heritage (Government of Galicia).

Supportive breeding based on artificial spawning of native adults has been employed since 1997 in the Ulla River to enhance the natural salmon population. The restocking program started in 2000 and is ongoing, but no restocking was conducted from 1992 to 1999 at this river. Only reared parr have been released in the Ulla River. Fish were released in autumn and at different places up- and downstream Ximonde, but always above the river mouth. All those salmon from restocking programs can be easily identified by the absence of their adipose fin, clipped before their release.

The river flow has been also included in the model to assess its effect on the number of returning salmons. River flow is the factor most frequently reported to control upstream migration of Atlantic salmon (Jonsson, 1991) and numerous studies have shown that increased water discharge stimulates Atlantic salmon to enter rivers from the sea (e.g. Thorstad et al., 2008). Water discharge may affect migration on natural river sections without migration barriers, as well as migration past various natural and man-made obstacles. Available records from a nearby gauging station (Ulla-Teo, station 554, about $8 \mathrm{~km}$ downstream) were used.

\section{Data analysis}

Regression models are designed to accommodate dependence relations between random variables. In the simplest case, considering a response variable $\mathrm{Y}$ and an explanatory variable $\mathrm{X}$, the linear regression model assumes that the slope of the fitted line is constant. In other words, this slope does not depend on the value of the explanatory variable $X$, something that may not be realistic in practice. In this work, a segmented regression model for accommodating broken-line relationships between $\mathrm{Y}$ and $\mathrm{X}$ will be considered.

Segmented regression models are characterised by the existence of a value in the explanatory variable (the so called break-point) which induces a change in the values of the trend or slope parameters for the regression function, but keeping the regression function continuous. In particular, a segmented version of the simple linear regression model can be written as follows:

$$
\begin{aligned}
& Y_{i}=\beta_{0}+\beta_{1} X_{i}+\beta \psi\left(X_{i}-\psi\right)_{+}+\varepsilon_{i} \\
& i=1, \ldots, n
\end{aligned}
$$

where $\left(X_{i}-\psi\right)_{+}=\left(X_{i}-\psi\right) I\left(X_{i}>\psi\right)$ with $\mathrm{I}($.$) denot-$ ing the indicator function and $\left(\varepsilon_{i}, \ldots, \varepsilon_{n}\right)$ denotes the vector of errors. Note that the two resultant pieces (before and after the break-point $\psi$ ) are straight lines with possibly different slopes, joining at point $X=\psi$. In particular, $\beta_{1}$ is the slope of the model when $X_{i} \leq \psi$ and $\beta_{1}+\beta \psi$ is the slope when $X_{i}>\psi$. Equivalently, $\beta \psi$ can be seen as the difference between the first and second model slopes. Since the existence of the break-point is assumed, it is supposed that $\psi \neq 0$.

Of course, if there are two or more explanatory variables, a multiple linear regression model can be considered. As before, there are practical situations where it seems natural to assume the existence of a segmented (broken-line) relationship. In particular, if the problem is simplified assuming the existence of two explanatory variables $X_{1}$ and $X_{2}$ and a single broken-line relation- 
ship with $X_{1}$, the segmented model could be written as follows:

$$
\begin{aligned}
& Y_{i}=\beta_{0}+\beta_{1} X_{1, i}+\beta \psi\left(X_{1, i}-\psi\right)_{+}+\beta_{2} X_{2, i}+\varepsilon_{i} \\
& i=1, \ldots, n
\end{aligned}
$$

where, as before, $Y_{i}$ denotes the response variable; $X_{1, i}$, the segmented explanatory variable; $\left(X_{1, i^{-}} \psi\right)_{+}=\left(X_{1, i^{-}} \psi\right) I\left(X_{1, i}>\psi\right)$, being $X_{2, i}$ another covariate which does not affect the break-point.

Regarding the segmented model (1) different estimation procedures have been proposed in literature. Sprent (1961) assumed that the break-point is known and the parameters are estimated using a least squares procedure. Hinkley (1969) developed a method for estimating the trend parameters, implementing an algorithm which tries to find the interval that maximizes the model likelihood function and then it determines the cut point of two straight lines inside this interval. Hudson (1966) proposed a similar method, but minimising the squared sum of residuals. An alternative approach, based on Taylor approximations and possibly more than a single break-point, was recently proposed by Muggeo (2003).

The method introduced by Muggeo (2003) assumes the existence of a break-point and this fact is not always guaranteed. Therefore, this hypothesis must be tested before proceeding with model estimation. In particular, Davies and Score tests can be used to assess a non-zero difference-in-slope parameter of a segmented relationship. For model (1), the null hypothesis to be tested can be written as $H_{0}: \beta \psi=0(\beta \psi=0$ means no breakpoint). In fact, Muggeo (2003) verifies the existence of a break-point using Davies test. See Davies $(1987,2002)$ and Muggeo (2016) for more details.

A note of caution should be made at this point. The nature of our observations (measurements of different variables collected along time) may pose some complications when estimating the different models, given that there may exist some temporal correlation. Certainly, this issue should be tested to avoid compromising the conclusions derived from a model fit based on independent observations. In our specific application, model fits will be validated to assess the hypotheses which support inferential conclusions. For instance, Breusch-Godfrey test [see Breusch (1978) and Godfrey (1978)] can be used for testing higher-order serial correlation.

All statistical analyses reported in this work were performed using the version $0.5-3.0$ of the segmented package for $\mathrm{R}$. Given a regression model, this package updates it by adding one or

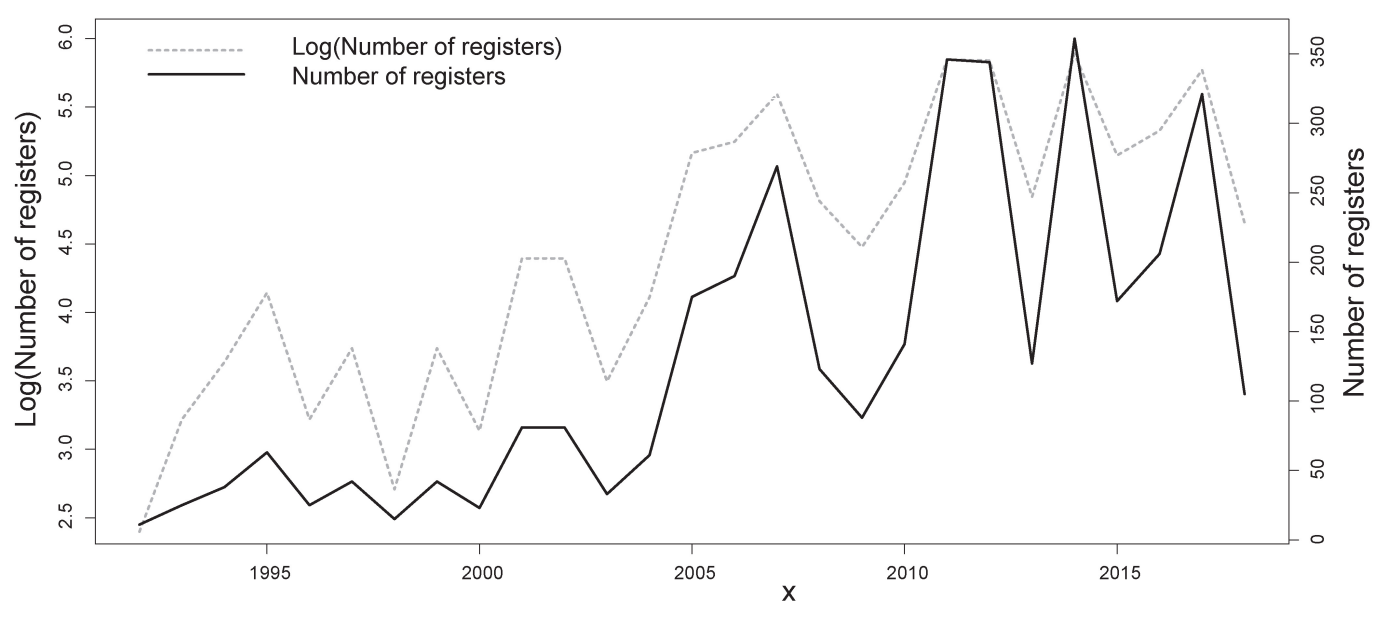

Figure 1. Time series of the number of returning salmons (black line) and logarithm of the number of returning salmons (dashed gray line) registered in Ximonde from 1992 to 2018. Serie temporal del número de salmones de retorno (línea negra) y del logaritmo del número de salmones de retorno (línea discontinua gris) registrados en Ximonde de 1992 a 2018. 
more segmented relationships. The analysis was performed in R 3.5.3 (R Core Team 2019).

\section{RESULTS}

\section{Multiple linear regression model}

A multiple linear regression model was fitted considering as response $\mathrm{Y}$, the annual time series of the logarithm of number of returning salmons registered in Ximonde from 1992 to 2018; as explanatory variables $X_{1}$, the year, and $X_{2}$, the average of means for upper and lower water levels. Since the time series of the number of returning salmons shown in Figure 1 presents a certain degree of heteroscedasticity, it was necessary to consider a natural logarithm transformation (see also Fig. 1). The explanatory variable $X_{2}$ is represented in Figure 2 (note that there are some missing data).

Before proceeding with a linear model estimation, it is necessary to check if there exists a real linear relationship between $\mathrm{Y}$ and the explanatory variables $X_{1}$ and $X_{2}$ for fitting the multiple linear regression model. In Figure 3, a scatterplot matrix of these three variables is shown. In addition, the strength of these linear relationships is shown by the Pearson linear correlation coefficients (Table 1). A signifi- cance test on the linear correlation coefficient indicates that the correlation between $\mathrm{Y}$ and $X_{1}$ is not null ( $p$-value $<0.001)$, whereas the correlation between the response and $X_{2}$ is not significantly different from zero $(p$-value $=0.106)$.

After these preliminary checkings, a summary for the fitted multiple linear model is shown in Table 2. The value of the residual standard error obtained is 0.53 and the multiple R-squared, 0.65 . The value of F-statistic is 17.03 and the corresponding $p$-value, $7 \cdot 10^{-5}$. Therefore, this model presents an acceptable value for $\mathrm{R}$-squared and a very low critical value for the $\mathrm{F}$ test. Consequently, it seems that the two explanatory variables considered are useful for explaining the logarithm of the number of salmons, given that the proportion of variability explained is non negligible. Although linear relationship between $\mathrm{Y}$ and $X_{2}$ did not seem evident, all model coefficients are significant.

When we use a linear regression model on time series data, we are implicitly making some assumptions on the variables and the residuals. Apart from a linear relationship between the dependent variable and the predictor variables, we assume that the errors have mean zero and they are normally distributed with constant variance; they are not autocorrelated; they are independent of the predictor variables.

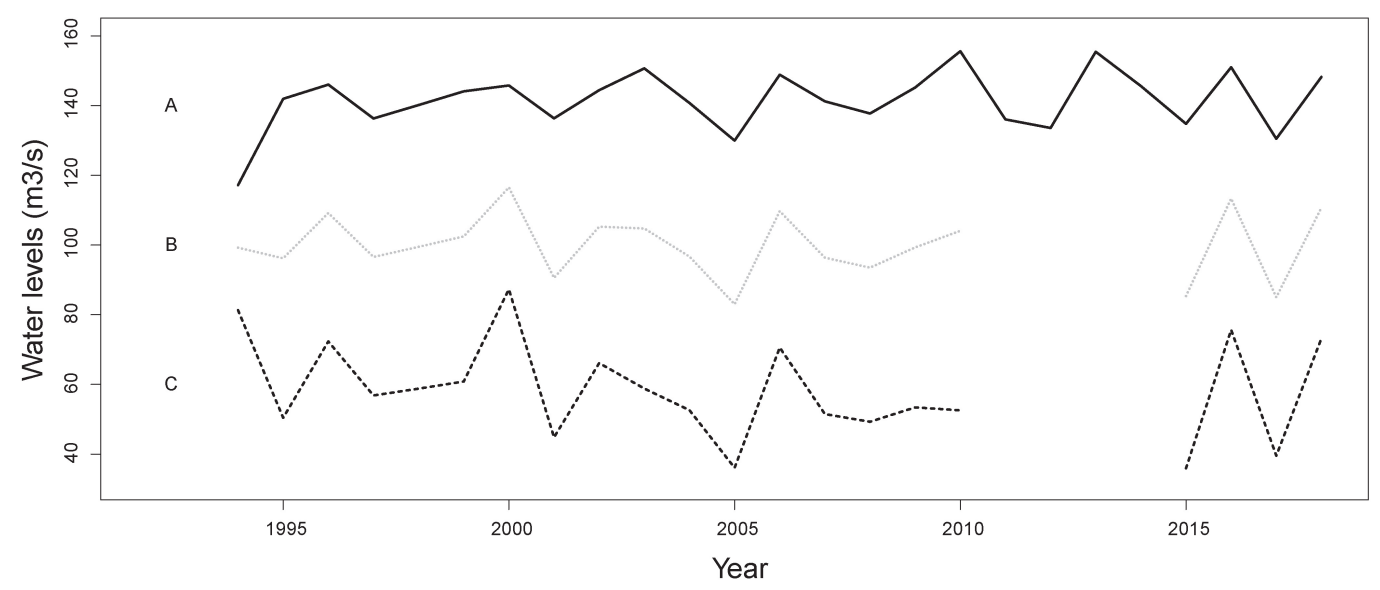

Figure 2. Time series for the mean of the upper (black line, A), lower (dashed line, B) and average (dotted line, C) water levels by year from 1992 to 2018 in the Ulla River. Serie temporal de la media anual de los niveles de agua superior (linea negra, A), medio (línea discontinua, B) e inferior (línea punteada, C) en cada año de 1992 a 2018 en el río Ulla. 


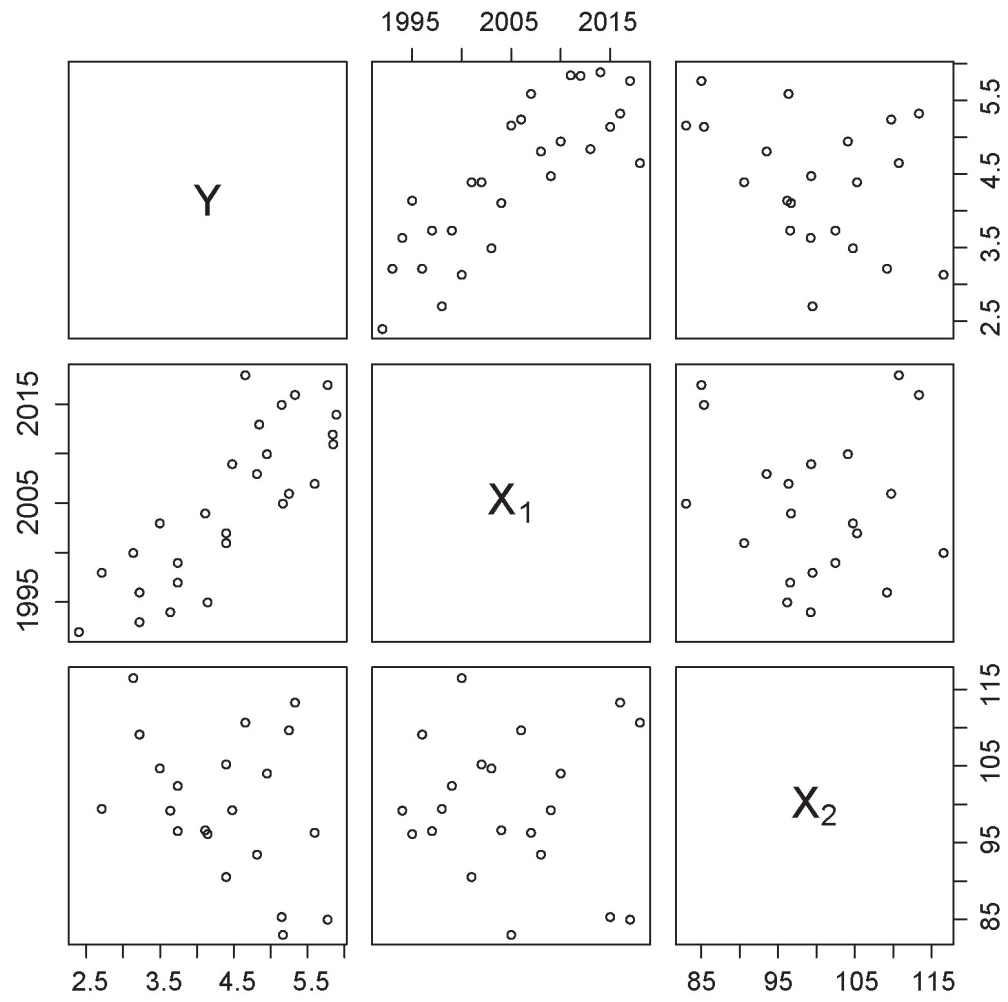

Figure 3. Scatterplot matrix of $\mathrm{Y}, X_{1}$ and $X_{2}$ variables where $\mathrm{Y}$ denotes the logarithm of number of salmons registered by year; $X_{1}$, the variable year and $X_{2}$, the average of means for upper and lower water levels. Matriz de diagramas de dispersión de las variables $Y, \mathrm{X}_{1}$ y $\mathrm{X}_{2}$ donde $Y$ denota el logaritmo del número de salmones registrados por año; $\mathrm{X}_{1}$, la variable año y $\mathrm{X}_{2}$, el promedio de los niveles de agua superior e inferior.

Table 1. Pearson linear correlation coefficients where $Y$ corresponds to the annual time series of the logarithm of number of returning salmons registered in Ximonde from 1992 to $2018 ; X_{1}$ denotes the variable year and $X_{2}$, the average of means for upper and lower water levels. Coeficientes de correlación linear de Pearson donde Y se corresponde con la serie de tiempo anual del logaritmo del número de salmones registrados en Ximonde desde 1992 hasta 2018; X 1 denota la variable año y $\mathrm{X}_{2}$, el promedio de las medias para los niveles de agua superior e inferior.

\begin{tabular}{cccc}
\hline & $\mathrm{Y}$ & $X_{1}$ & $X_{2}$ \\
\hline $\mathrm{Y}$ & 1 & & \\
$X_{1}$ & 0.75 & 1 & \\
$X_{2}$ & -0.36 & 0.092 & 1 \\
\hline
\end{tabular}

Table 2. Multiple linear regression fitting. The response variable $\mathrm{Y}$ is the annual time series of the logarithm of number of returning salmons registered in Ximonde from 1992 to 2018; the explanatory variables $X_{1}$ and $X_{2}$ corresponds to the year and the average of means for upper and lower water levels, respectively. The coefficient $\beta_{0}$ represents the estimation of the model constant; $\beta_{1}$ and $\beta_{2}$, the coefficients corresponding to the variables $X_{1}$ and $X_{2}$, respectively. Ajuste mediante regresión lineal múltiple. La variable respuesta es la serie de tiempo anual del logaritmo del número de salmones registrados en Ximonde desde 1992 hasta 2018; las variables explicativas se corresponden con el año y el promedio de las medias para los niveles de agua superior e inferior, respectivamente. El coeficiente $\beta_{0}$ representa la estimación de la constante del modelo; $\beta_{1}$ y $\beta_{2}$, los coeficientes correspondientes a las variables $\mathrm{X}_{1}$ y $\mathrm{X}_{2}$, respectivamente.

\begin{tabular}{ccccc}
\hline & Estimate & Std. Error & t-value & $p$-value \\
\hline$\beta_{0}$ & -162.46 & 32.65 & -4.98 & $<0.0001$ \\
$\beta_{1}$ & 0.08 & 0.02 & 5.22 & $<0.0001$ \\
$\beta_{2}$ & -0.03 & 0.01 & -2.12 & 0.05 \\
\hline
\end{tabular}


In our analysis, residuals are slightly skewed and the autocorrelation function plot does not show any significant spike. In fact, the $p$-value of the Breusch-Godfrey test for serial correlation of order up to 6 is not significant. Therefore, it is plausible to assume that the residuals are uncorrelated.

In addition, we would expect the residuals to be randomly scattered showing no pattern. A simple way to check this is to examine the scatterplots of the residuals against each of the predictor variables. These scatterplots show a random pattern and therefore these findings do not contradict the linear relationship. Furthermore, no pattern is observed when residuals are represent- ed against the fitted values. Thus, a common variance can be assumed for all the errors.

When X_1 is included in the discussed multiple linear regression model as the segmentation variable the estimated break-point using Muggeo's method corresponds to year 2007. Furthermore, according to the results obtained, the logarithm series is fitted by equation $Y_{i}=-239.79+$ $0.12 X_{1, i}-0.03 X_{2, i}$ before 2007 ; and by equation $Y_{i}=-63.87+0.04 X_{1, i}-0.03 X_{2, i}$ after 2007 (see Figure 4 for more details). The fitted model for the transformation time series of the logarithm of the number of returning salmons is shown in Figure 5.
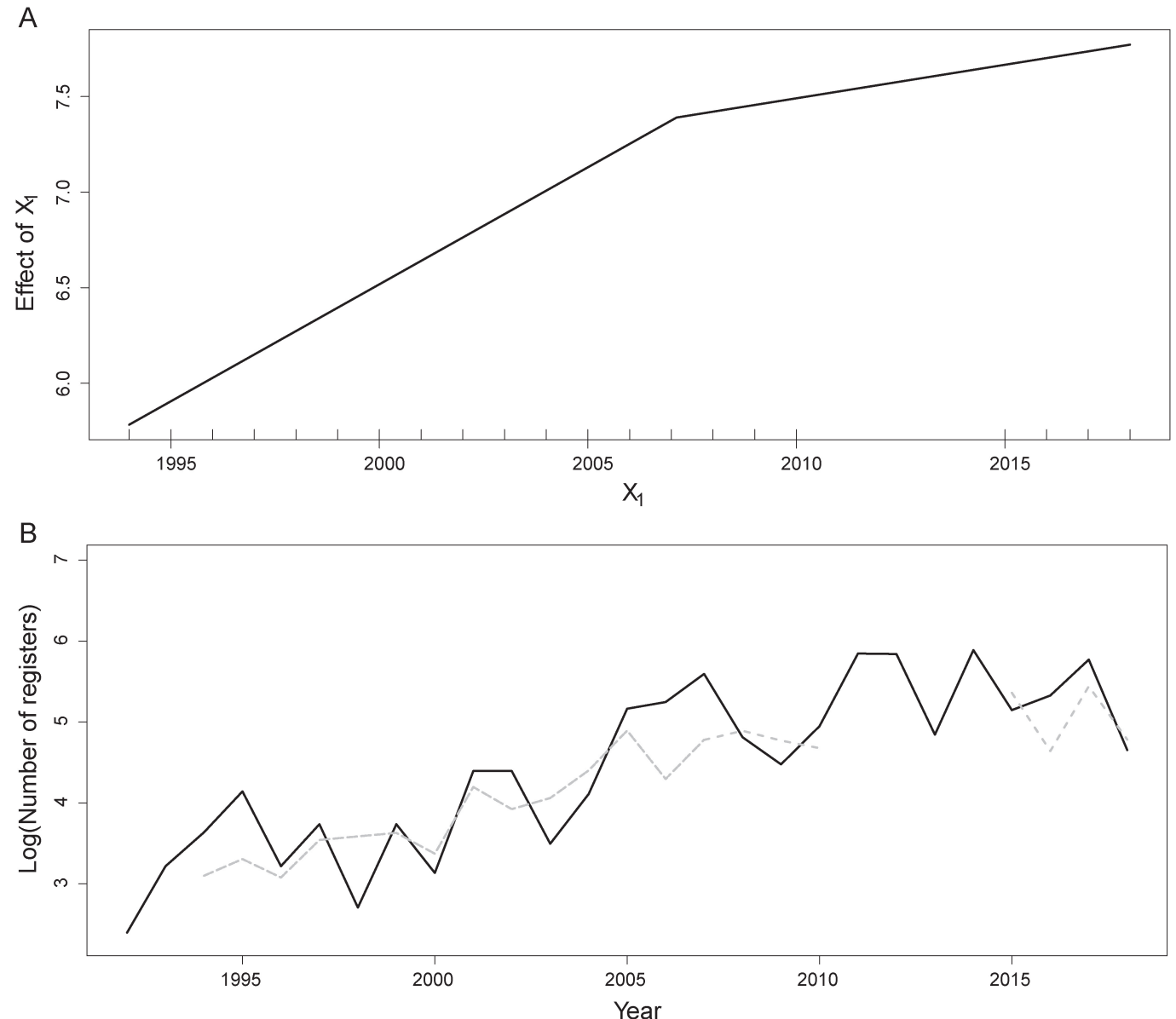

Figure 4. Fitted broken-line for the selected segmented term (top) and fitted model (bottom, dotted line) for the logarithm of the number of returning salmons registered in Ximonde from 1992 to 2018 (bottom, black line). Linea segmentada ajustada para el término segmentado seleccionado (arriba) y modelo ajustado (abajo, línea de puntos) para el logaritmo del número de salmones de retorno registrados en Ximonde de 1992 a 2018 (abajo, línea negra). 

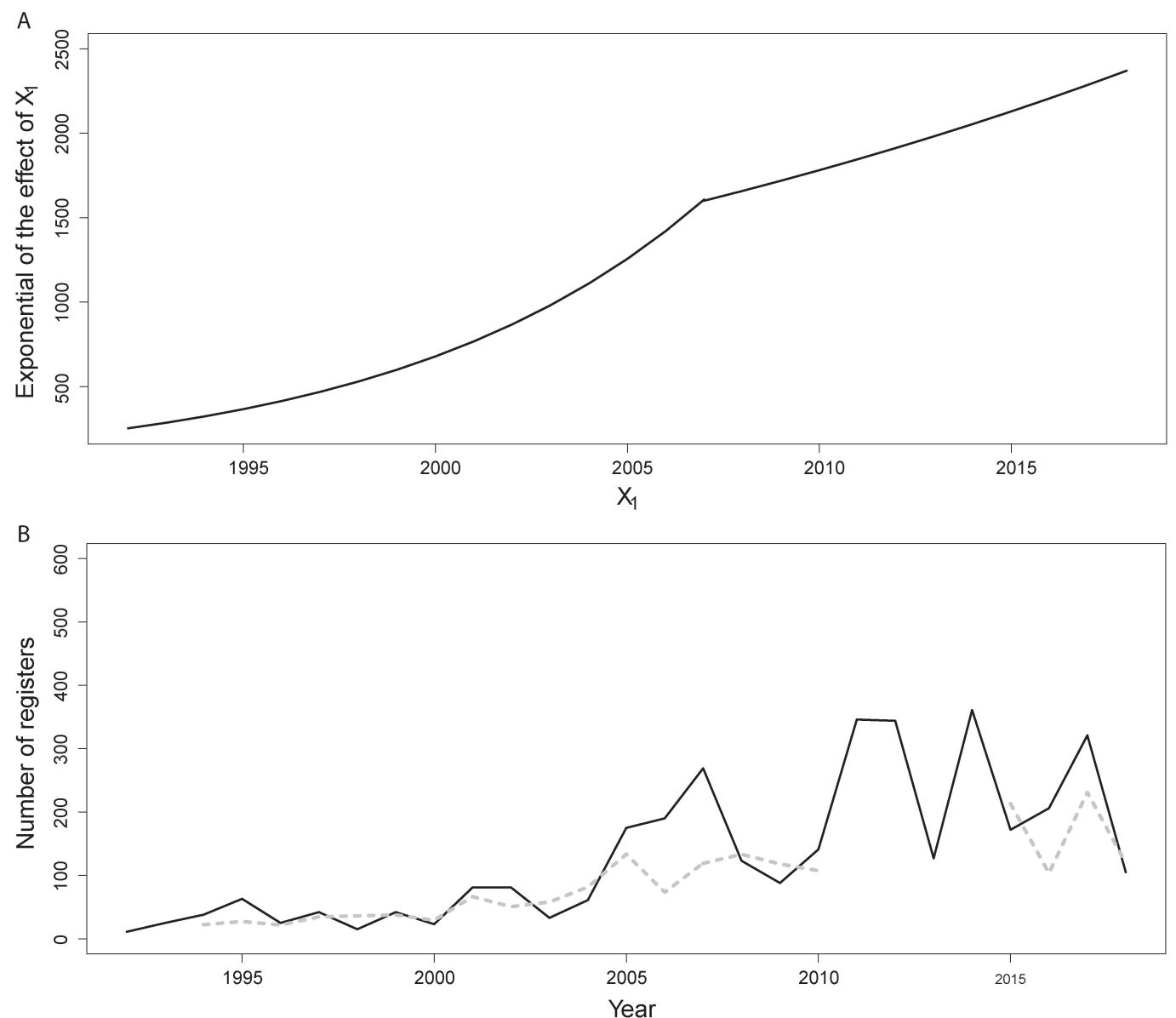

Figure 5. Exponential of the fitted broken-line for the selected segmented term (top) and fitted model (bottom, red line) for the number of returning salmons registered in Ximonde from 1992 to 2018 (bottom, black line). Exponencial de la linea segmentada ajustada para el término segmentado seleccionado (arriba) y modelo ajustado (abajo, línea de puntos) para el número de salmones de retorno registrados en Ximonde de 1992 a 2018 (abajo, linea continua).

In the current application, the $p$-values obtained for Davies and Score tests conclude that there are no evidences against a linear model without change-points ( $p$-values 0.61 and 0.38 , respectively). However, the reduced sample size may lead to a lack of significance of any test. From a different point of view, it should be noted that the prediction error is lower for the segmented model, when compared to the non-segmented one (specifically, the mean square prediction error for the segmented model is 2556.12, and for the non-segmented model is 3384.88). In addition, there are serious practical concerns which support the existence of this break-point, such as an increase in wild salmon numbers from 2007 and the removal of a small dam in 2004; so, a segmented model will be considered for our data.

\section{Age at sea and effect of wild specimens}

Results show (Fig. 6) that annual mean sea age only exceeds 2SW in the year 2011. Nevertheless, the frequency of $3 \mathrm{SW}$-aged specimens $(\mathrm{SW}=$ sea winters) increased, though not statistically significantly so, since 2009.

Regarding the temporal evolution of restocked and wild salmon captured at Ximonde trap (Fig. 7) the model shows that, in coincidence 
with the detected break point in 2007, a more important entry of wild specimens occurred. Wild salmon represented an $82.70 \%$ of the total captured specimens from 2000 to 2018 , but again the Davies and Score tests are not statistically significant if data of that period are compared with those from 1992 to 1999.

\section{DISCUSSION}

Our results suggest that segmented regression analysis is a useful tool for determining the break-point at which a change in trend occurs in the number of salmon returning to the Ulla River, given that the variability explained is non negligible and all model coefficients are significant. Using Muggeos's method the analysis detected a break-point in 2007 for the number of returning salmon, and although sample size seems to be small for achieving robustness the results support the existence of this break-point.

The analysis of the data compiled at Ximonde fish trap suggests a gradual increase in the number of post-smolts entering the Ulla River to the early 1990s after which the population has remained relatively stable until 2007 and increased thereafter due to an increase in the number of wild salmon specimens.

Nevertheless, there can be no assurance that the detected break-point in 2007 was due solely to the restocking program. Given that there are no commercial fisheries for Atlantic salmon in Northern Spain as marine exploitation is banned in Spanish waters and sport fisheries management results in constant fishing pressure from year to year, at least two other known factors must be taken into account to evaluate the change in the adult stock catched at Ximonde. On the one hand, a higher marine survival rate due to the decline in the salmon fisheries at sea and, on the other hand, the construction of a fish ladder downstream the Ximonde trap in 2004.

According to Nicola et al. (2018) there was a sharp decline in returning salmon in the 1970s, possibly triggered by overfishing at sea and a sudden outbreak of disease (Mills, 1989). And also, in the 1960s and 1980s a huge interceptory commercial salmon fishing existed in the open sea around the coasts of Greenland and the Faeroes, the assumed feeding areas of Spanish salmon (Jacobsen et al., 2012; Reddin et al., 2012; Nicola et al., 2018). However, exploitation of Atlantic salmon in the North Atlantic has declined since the 1990s because of both decreased salmon productions and decreased fishing effort, i.e. due to strong regulation of marine fisheries especially during the 1980s and 1990s. In fact, according to the North Atlantic Salmon Conservation Organization (NASCO), there has been no commercial salmon fishery around the Faroes since the early

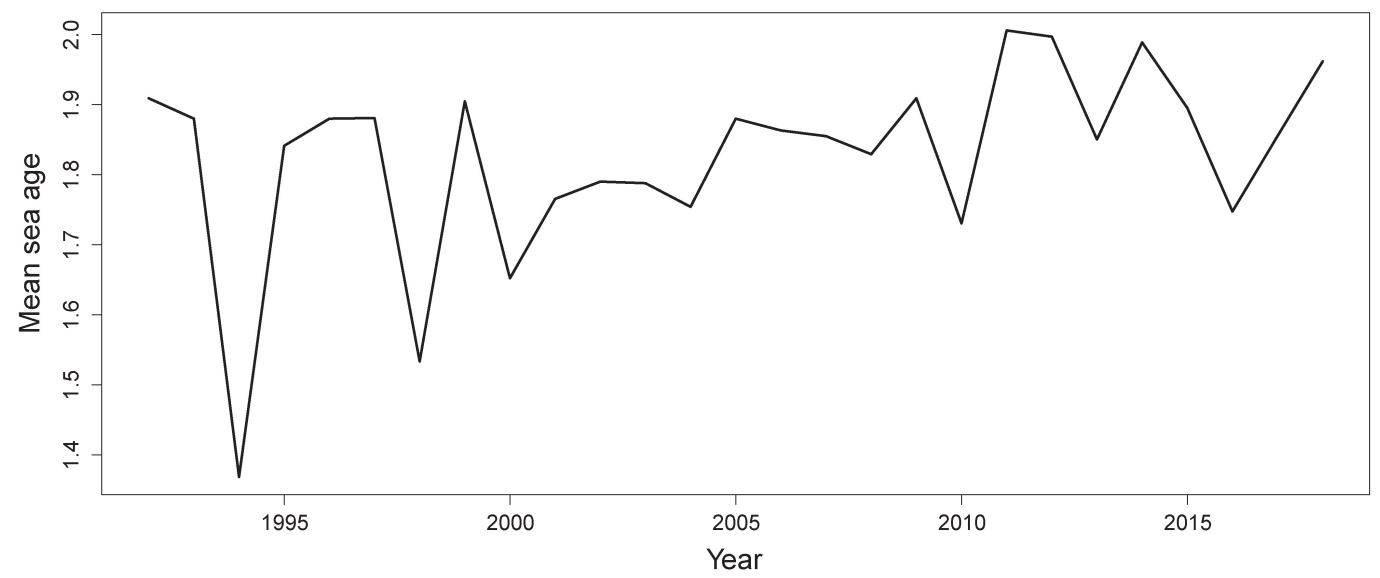

Figure 6. Temporal evolution of the annual mean sea age of the returning salmons captured at Ximonde trap from 1992 to 2018. Evolución temporal de la edad media marina anual de los salmones de retorno capturados en la trampa de Ximonde de 1992 a 2018. 
1990s, and the Greenland fishery is currently an internal-use fishery (Windsor et al., 2012). Thus, the regulation of marine fisheries in these areas since the early 1990s and decreased fishing effort may have resulted in the observed increase of the restocked specimens entering the Ulla River since 2001. Moreover, even though the results are not statistically significant, the increase in the frequency of appearance of $3 \mathrm{SW}$ specimens since the year 2009 detected in our analysis also supports this argument.

Among the 3SW salmons catched at Ximonde trap, previous spawners were detected after scale reading, but also individuals at its first spawning migration after three consecutive winters at sea. This suggests an increase in the number of wild salmon entering the river and accessing the trap. Furthermore, although returns of stocked salmon in the Ulla River are significantly lower than returns of wild fish, as has been usually reported (Jonsson et al., 2003; Saloniemi et al., 2004; Morán et al., 2005), both restocked and wild specimens were captured in much larger numbers since 2005. This change matches in time with the construction of a vertical slot fish ladder at Couso dam (about $12 \mathrm{~km}$ downstream Ximonde trap) in
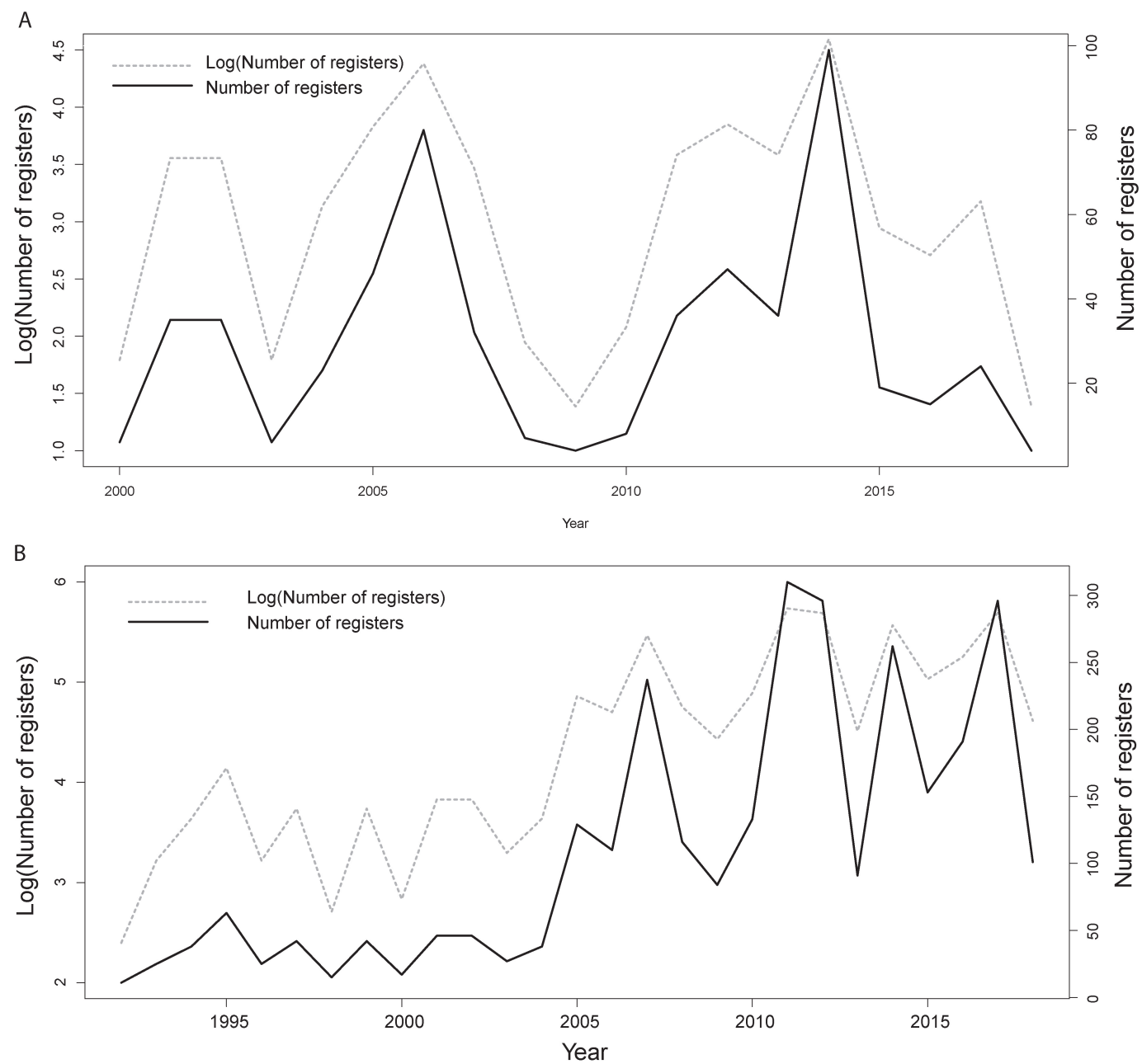

Figure 7. Temporal evolution of restocked (top) and wild (bottom) returning salmons captured at Ximonde trap (Restocked from 2000 to 2018; wild from 1992 to 2018). Evolución temporal de los salmones de retorno repoblados (arriba) y salvajes (abajo) capturados en la trampa de Ximonde (Repoblados entre 2000 y 2018; salvajes entre 1992 y 2018). 
2004, which seems to have improved the upstream migration and making the trap more accessible for returning salmon. No other noticeable change was made in the river downstream Ximonde that year.

Thus, although a similar pattern to that detected in the Ulla River can be inferred from data from some other European populations (Baglinière et al., 2005; Aprahamian et al., 2008; Erkinaro et al., 2018) and also from data from some rivers in northern Spain (Álvarez et al., 2010; Barquín et al., 2012), further studies in other Spanish rivers covering a similar time series would be necessary to confirm the evolution of the stock detected in the river Ulla.

Migrating fish may experience costly delays in small dams (Marschall et al., 2011; Thorstad et al., 2008) related to increased susceptibility to disease, illegal fishing, predation and sport fishery mortality (García de Leaniz, 2008; Gowans et al., 2003). Thus, restoration of connectivity seems to be the best management action for recovery and enhancement of Atlantic salmon populations (Horreo et al., 2011b; ICES, 2018b).

The use of segmented regression following the Muggeo's method has been proved useful for assessing the success of a stoking program carried out in the Ulla River over 27 years. The analysis detected a break-point for the returning salmon data series (year 2007) and the restocking program seems to be effective. Nevertheless, the temporal evolution of the post-smolt stock arriving at Ximonde also suggest that at least two other synergetic factors must be taken into account. The first is a higher marine survival rate due to the decline in the salmon fisheries at sea. The second and probably more relevant from local perspective, the construction of a fish ladder downstream the Ximonde trap in 2004. Therefore, our findings also highlight the need to safeguard longitudinal river connectivity by enabling two-way passage for fish at migration obstacles to ensure long term success of migratory species conservation and management programs.

Although changes in the marine environment surely are the forcing factor controlling stock salmon productivity, improved conditions in freshwater may be the more important factor in ensuring the success of recovery programs.

\section{ACKNOWLEDGEMENTS}

This study was carried out in the 'Encoro do Con' Hydrobiological Field Station of the USC at Vilagarcía de Arousa. The authors are grateful to the Xunta de Galicia for making available the specimens' datasets for this study. We are also particularly thankful to the staff at Ximonde trap, namely Manuel García Rego, Jose Antonio Garea Gil and Jose Manuel Cancela, who went beyond their job in their personal commitment in data collection over the years. River flow values were provided by the Servizo de Planificación e Programación Hidrolóxica (Demarcación Hidrográfica Galicia-Costa, Augas de Galicia, Consellería de Infraestruturas e Mobilidade, Xunta de Galicia). P. Saavedra-Nieves and R.M. Crujeiras acknowledge the support of MTM2016-76969P from the Ministry of Economy and Competitiveness and ERDF.

\section{REFERENCES}

ALVAREZ, J., A. ANTÓN, I. AZPIROZ, P. CABALLERO, F. HERVELLA, J. HOZ, M. LAMUELA, I. MENDIOLA, J. MONGE, A. SERDIO \& I. URRIZALKI. 2010. Atlas de los rios salmoneros de la Península Ibérica. Ekolur SLL, Guipuzcoa, Spain.

APRAHAMIAN, M. W., K. M. SMITH, P. MCGINNITY, S. MCKELVEY \& J. TAYLOR. 2003. Restocking of salmonids opportunities and limitations. Fisheries Research, 62: 211 - 227.

APRAHAMIAN, M. W., I. C. DAVIDSON \& R. J. COVE 2008. Life history changes in Atlantic salmon form the River Dee, Wales. Hydrobiologia, 602: 61 - 78 .

ARAKI, H., B. COOPER \& M. S. BLOUIN. 2007. Genetic effects of captive breeding cause a rapid, cumulative fitness decline in the wild. Science, 318: 100 - 103.

ARAKI, H., B. A. BEREJIKIAN, M. J. FORD \& M. S. BLOUIN. 2008. Fitness of hatchery-reared salmonids in the wild. Evolutionary Applications, 1: 342 - 355.

ARAKI, H., B. COOPER \& M. S. BLOUIN. 2009. Carry-over effect of captive breeding reduces reproductive fitness of wild-born descendants in the wild. Biology Letters, 5: 
$621-624$

AYLLON, F., J. L. MARTINEZ \& E. GARCIA-VAZQUEZ. 2006. Loss of regional population structure in Atlantic salmon, Salmo salar L., following stocking. ICES Journal of Marine Science, 63, 1269 - 1273.

BACON, P. J., I. A. MALCOLM, R. J. FRYER, R. S. GLOVER, C. P. MILLAR \& A. F. YOUNGSON. 2015. Can conservation stocking enhance juvenile emigrant production in wild Atlantic salmon? Transactions of the American Fisheries Society, 144: 642 - 654.

BAGLINIÈRE, J-L., F. MARCHAND \& V. VAUCLIN. 2005. Interannual changes in recruitment of the Atlantic salmon (Salmo salar) population in the River Oir (Lower Normandy, France): Relationships with spawners and in-stream habitat. ICES Journal of Marine Science, 62: 695 - 707.

BARQUÍN, J., B. ONDIVIELA, M. RECIO, M. ÁLVAREZ-CABRIA, F. J. PEÑAS, D. FERNÁNDEZ, A. GÓMEZ, C. ÁLVAREZ \& J. A. JUANES. 2012. Assessing the conservation status of alder-ash alluvial forest and Atlantic salmon in the Natura 2000 river network of Cantabria, Northern Spain. In: River conservation and management. P. J. Boon \& P. J. Raven (eds.): 193 - 210. Willey-Blackwell. Chichester. UK.

BRENDEN, T. O. \& J. R. BENCE. 2008. Comment: Use of piecewise regression models to estimate changing relationships in fisheries. North American Journal of Fisheries Management, 28(3): $844-846$.

BLANCO, G., M. D. RAMOS, E. VAZQUEZ \& J. A. SÁNCHEZ. 2005. Assessing temporal and spatial variation in wild populations of Atlantic salmon with particular reference to Asturias (Northern Spain) rivers. Journal of Fish Biology, 67(A): $169-184$.

BRAÑA, F., GARRIDO, R. \& A. G. NICIEZA. 1995. Historical changes in age structure of Atlantic salmon, Salmo salar L., in the river Eo, northern Spain. Fisheries Management and Ecology, 2: 179 - 187.

BREUSCH, T. S. 1978. Testing for Autocorrelation in Dynamic Linear Models. Australian Economic Papers, 17: 334 - 355.

CAMPOS, J. L., D. POSADA \& P. MORÁN.
2008. Introgression and genetic structure in northern Spanish Atlantic salmon (Salmo salar L.) populations according to mtDNA data. Conservation Genetics, 9: 157 - 169.

CHRISTIE, M. R., M. L. MARINE, R. A. FRENCH \& M. S. BLOUIN. 2012. Genetic adaptation to captivity can occur in a single generation. Proceedings of the National Academy of Sciences of the United States of America, 109: 238 - 242.

DAVIES, R. B. 1987. Hypothesis testing when a nuisance parameter is present only under the alternative. Biometrika, 74: 33 - 43.

DAVIES, R. B. 2002. Hypothesis testing when a nuisance parameter is present only under the alternative: linear model case. Biometrika, 89: 484 - 489.

EINUM, S. \& I. A. FLEMING. 2001. Implications of stocking: ecological interactions between wild and released salmonids. Nordic Journal of Freshwater Research, 75: 56 - 70.

ERKINARO, J., Y. CZORLICH, P. ORELL, J. KUUSELA, M. FALKEGÅRD, M. LÄNSMAN, H. PULKKINEN, C. R. PRIMMER \& E. NIEMELÄ. 2019. Life history variation across four decades in a diverse population complex of Atlantic salmon in a large subarctic river. Canadian Journal of Fisheries and Aquatic Sciences, 76(1): 42 - 55.

GARCÍA DE LEANIZ, C. 2008. Weir removal in salmonid streams: implications, challenges and practicalities. Hydrobiologia, 609: 83 - 96.

GODFREY, L. G. 1978. Testing against general autoregressive and moving average error models when the regressors include lagged dependent variables. Econometrica, 46: 1293 1301.

GOWANS, A., J. ARMSTRONG, I. PRIEDE \& S. MCKELVEY. 2003. Movements of Atlantic salmon migrating upstream through a fish-pass complex in Scotland. Ecological Freshwater Fish, 12: 177 - 189.

GURNEY, W. S. C., P. J. BACON, G. TYLDESLEY \& A. F. YOUNGSON. 2008. Processbased modelling of decadal trends in growth, survival and smolting of wild salmon (Salmo salar) parr in a Scottish upland stream. Canadian Journal of Fisheries and Aquatic Sciences, 65: 2606 - 2622. 
HINKLEY, D. V. 1969. Inference about the intersection in two-phase regression. Biometrika, 56: 495 - 504.

HORREO, J. L., G. MACHADO-SCHIAFFINO, F. AYLLON, A. M. GRIFFITHS, D. BRIGHT, J. R. STEVENS \& E. GARCIA-VAZQUEZ. 2011a. Impact of climate change and human-mediated introgression on South European Atlantic salmon populations. Global Change Biology, 17: 1778 - 1787.

HORREO, J. L., J. DE LA HOZ, G. MACHADO-SCHIAFFINO, I. G. POLA \& E. GARCIA-VAZQUEZ. 2011b. Restoration and enhancement of Atlantic salmon populations: what we have learned from North Iberian rivers. Knowledge and Management of Aquatic Ecosystems, 402: 996 - 999.

HORREO, J. L., G. MACHADO-SCHIAFFINO, A. M. GRIFFITHS, D. BRIGHT, J. R. STEVENS \& E. GARCIA-VAZQUEZ. 2011c. Atlantic salmon at risk: apparent rapid declines in effective population size in southern European populations. Transactions of the American Fisheries Society, 140: 605 - 610.

HUDSON, D. J. 1966. Fitting segmented curves whose join points have to be estimated. Journal of the American Statistical Association, 61: 1097 - 1129.

ICES 2013. Report of the Working Group on North Atlantic Salmon (WGNAS). 3 - 12 April 2013, Copenhagen, Denmark. ICES CM 2013/ACOM: 09.

ICES 2018a. Report of the Working Group on North Atlantic Salmon (WGNAS), 4-13 April 2018, Woods Hole, MA, USA. ICES CM 2018/ACOM:21.

ICES 2018b. ICES Advice on fishing opportunities, catch, and effort Northeast Atlantic ecoregions. DOI: 10.17895/ices.pub.4335

JACOBSEN, J. A., L. P. HANSEN, V. BAKKESTUEN, R, HALVORSEN, D. G., REDDIN, J. WHITE, N. O'MAOILÉIDIGH, I. C., RUSSELL, E. C. E., POTTER, M. FOWLER, G. W. SMITH, K. A. MORK, A. ISAKSSON, S. OSKARSSON, L. KARLSSON \& S. PEDERSEN. 2012. Distribution by origin and sea age of Atlantic salmon (Salmo salar) in the sea around the Faroe Islands based on analysis of historical tag recoveries.
ICES Journal of Marine Science, 69: 1598 1608 .

JOKIKOKKO, E. \& E. JUTILA. 1998. The effects of stocking with salmon parr, Salmo salar, on the smolt production in the River Simojoki, Northern Finland. In: Stocking and Introduction of Fish, I. G. Cowx (Ed.): 35 45. Fishing News Books, Blackwell, Oxford.

JOKIKOKKO, E., I. KALLIO-NYBERG, I. SALONIEMI \& E. JUTILA. 2006. The survival of semi-wild, wild and hatchery-reared Atlantic salmon smolts of the Simojoki River in the Baltic Sea. Journal of Fish Biology, 68: 430 - 442.

JONSSON, N. 1991. Influence of water flow, water temperature and light on fish migration in rivers. Nordic journal of freshwater research, 66: 20 - 35

JONSSON, B. \& N. JONSSON. 2009. A review of the likely effects of climate change on anadromous Atlantic salmon Salmo salar and brown trout Salmo trutta, with particular reference to water temperature and flow. Journal of Fish Biology, 75: 2381 - 2447.

JONSSON, N., B. JONSSON \& L. P. HANSEN. 2003. The marine survival and growth of wild and hatchery-reared Atlantic salmon. Journal of Applied Ecology, 40: 900 - 911.

KENNEDY, R. J., W. W. CROZIER \& M. ALLEN. 2012. The effect of stocking with $0+$ year age-class Atlantic Salmon Salmo salar fry: a case study from the River Bush, Northern Ireland. Journal of Fish Biology, 81: 1730 1746.

MACHADO-SCHIAFFINO, G., E. DOPICO \& E. GARCIA-VAZQUEZ. 2007. Genetic variation losses in Atlantic salmon stocks created for supportive breeding. Aquaculture, $264(1-4): 59-65$.

MARSCHALL, E. A., M. E. MATHER, D. L. PARRISH, G. W. ALLISON \& J. R. MCMENEMY. 2011. Migration delays caused by anthropogenic barriers: modeling dams, temperature, and success of migrating salmon smolts. Ecological Applications, 21: 3014 3031

MILLS, D. 1989. Ecology and Management of Atlantic Salmon. Chapman \& Hall, London.

MILOT, E., C. PERRIER, L. PAPILLON, J. J. 
DODSON \& L. BERNATCHEZ. 2012. Reduced fitness of Atlantic salmon released in the wild after one generation of captive breeding. Evolutionary Applications, 6: 472 - 485.

MORAN, P, J. PEREZ, J. DUMAS, E. BEALL \& E. GARCIA-VAZQUEZ. 2005. Stocking-related patterns of genetic variation at enzymatic loci in south European Atlantic salmon populations. Journal of Fish Biology, 67: 185 - 199.

MUGGEO, V. M. R. 2003. Estimating regression models with unknown breakpoints. Statistics in Medicine, 22: 3055 - 3071.

MUGGEO, V. M. R. 2016. Testing with a nuisance parameter present only under the alternative: a score-based approach with application to segmented modelling. Journal of Statistical Computation and Simulation, 86: 3059 - 3067.

NICOLA, G. G., B. ELVIRA, B. JONSSON, D. AYLLÓN \& A. ALMODÓVAR. 2018. Local and global climatic drivers of Atlantic salmon decline in southern Europe. Fisheries Research, 198: 78 - 85.

PARRISH, D. L., R. J., BEHNKE, S. R., GEPHARD, S. D. McCORMICK \& G. H. REEVES. 1998. Why aren't there more Atlantic salmon (Salmo salar)?. Canadian Journal of Fisheries and Aquatic Sciences, 55: 281 - 287.

PÉREZ, J., J. I. IZQUIERDO, J. DE LA HOZ \& E. GARCÍA-VÁZQUEZ. 2005. Female biased angling harvests of Atlantic salmon in Spain. Fisheries Research, 74: 127 - 133.

R CORE TEAM (2019) $R$ : A language and environment for statistical computing. Vienna, Austria: R Foundation for Statistical Computing. URL https://www.R-project.org REDDIN, D. G., L. P. HANSEN, V. BAKKESTUEN, I. RUSSELL, J. WHITE, E. C. E. POTTER, J. B. DEMPSON, T. F. SHEEHAN, N. O'MAOILÉIDIGH, G. W. SMITH, A.
ISAKSSON, J. A. JACOBSEN, M. FOWLER, K. A. MORK \& P. AMIRO. 2012. Distribution and biological characteristics of Atlantic salmon (Salmo salar) at Greenland based on the analysis of historical tag recoveries. ICES Journal of Marine Science, 69: 1589 - 1597.

RINCÓN, P. A. \& J. LOBÓN-CERVIÁ. 2002. Nonlinear self-thinning in a stream-resident population of brown trout (Salmo trutta). Ecology, 83: 1808 - 1816.

ROSENFELD, J. S. \& J. TAYLOR. 2009. Prey abundance, channel structure and the allometry of growth rate potential for juvenile trout. Fisheries Management and Ecology, 16: 202 218.

SALONIEMI, I., E. JOKIKOKKO, I. KALLIO-NYBERG, E. JUTILA \& P. PASANEN. 2004. Survival of reared and wild Atlantic salmon smolts: size matters more in bad years. ICES Journal of Marine Science, 61: 782 787.

SONDEREGGER, D. L., H. WANG, W. H. CLEMENTS \& B. R. NOON. 2009. Using SiZer to detect thresholds in ecological data. Frontiers in Ecology and the Environment, 7: 190 - 195.

SPRENT, P. 1961. Some hypotheses concerning two phase regression lines. Biometrics, 17, $634-645$.

THORSTAD, E.B., F. ØKLAND, K. AAARESTRP \& T. G. HEGGBERGET. 2008. Factors affecting the within-river spawning migration of Atlantic salmon, with emphasis on human impacts. Reviews in Fish Biology and Fisheries, 18: $345-371$.

WINDSOR, M. L., P. HUTCHINSON, L. P. HANSEN \& D. G. REDDIN. 2012. Atlantic salmon at sea: Findings from recent research and their implications for management. NASCO document CNL(12)60. Edinburgh, UK. 